\title{
Performance Analysis and Irrigation Scheduling For a Part of Parambikulam Aliyar Project Using Cropwat and Remote Sensing
}

\author{
K. Elangovan ${ }^{1}$ \\ \{ela.civil@psgtech.ac.in\}
}

${ }^{1}$ Professor, Department of Civil Engineering, PSG College of Technology, Coimbatore 641004

\begin{abstract}
Agriculture is the backbone of Indian economy, contributing about $22 \%$ to the country's GDP. Fifty years since the first green revolution, innovations in the field of agriculture have lost vigor and India lags behind others developed countries with respect to the efficiency of the irrigation systems. Developments haven't occurred to cope with the burgeoning population and it is becoming increasingly difficult to feed the billion mouths of the country. This research was undertaken with an aim to estimate the efficiency of an existing irrigation system and to propose changes in the system (if necessary) so that the scarcely available water resources are utilized economically. This paper introduces the use of modern tools like Remote Sensing, Geographic Information Systems (GIS) and CROPWAT to improve the management of the existing irrigation systems. Crop identification at distributary level was made from Remote Sensing satellite images, using image processing techniques, such as supervised and unsupervised classification. The cropping pattern and the area of land under each crop were identified using IRS-1D, LISS-III satellite image. Satellite Image Processing was carried out using ERDAS Imagine 8.4. For the purpose of delineating the study area in the satellite image, the study area was digitized in Arc View GIS 3.2a using Survey of India topo-sheets as a base map. At the end of the study, a comparison has been made between the existing system and the system proposed. Cropped areas were calculated for each individual crop from these classified images, and then crop water requirement at distributary level was estimated using CROPWAT. The results of this study can be used while devising guidelines by the government to release the canal supplies based on crop water requirement. This practice will help in avoiding wastage of canal water at farm level, which can be optimally used for increasing irrigated areas and crop productivity in the area.
\end{abstract}

Keywords: Geographic Information Systems, IRS, Soil, Water.

\section{Introduction}

Water is by far the most important resources for growth of plants and for obtaining good yield from the crops. Water performs the functions of supplying moisture to soil, water is essential for the germination of seeds, chemical and bacterial processes occurring during plant growth. Furthermore, water cools the soil and surroundings, thus making the environment more favorable for the plant growth. It also washes out and dilutes the soil of the harmful chemicals present in the 
soil. Water softens the clods, hence helps in tilling operations and water enables the application of fertilizers and their easy uptake by plants. Thus the proper application of water to the crop fields assumes the greatest significance while performing agriculture.

Bastiaanssen,. and Ali.( 2003) made a new crop yield-forecasting model based on satellite measurements applied across the Indus basin, Pakistan. Doorenbos and Pruitt (1975), provided guidelines for predicting crop water requirement. Applications of remote sensing in Geology was elaborated by Ravi (2005). Pat Hohl (1998) listed the GIS data conversion methods for various applications. Sechler, et al. (1998) studied the World water demand and supply and provided solution to tackle the issue. Zhao et al (2001) carried out a study on automatic abstraction methods of cultivated land information from satellite remote sensing images. Elangovan (2006) detailed the concepts of GIS and its application in various fileds.

\section{Objectives}

1. To calculate the actual annual water requirement of the various crops present in the Aliyar command area.

2. To propose a better cropping pattern for the Aliyar command area so that the available water resources are utilized economically.

3. To calculate the annual water requirement of the proposed cropping pattern and to make a comparison between them.

4. To develop a daily irrigation schedule - indicating the amount of water to be supplied to the fields - for the command area.

\section{Materials And Methods}

The Indian Remote Sensing Satellite (1RS-1D) digital data of LISS-III sensor, which provide a resolution of 23.25 meters, was utilized in the study. The satellite image has been used to identify the actual cropping pattern existing in the study area. The Path/Row for the IRS - 1D, LISS - III digital satellite data was 100-66. The date of pass of the satellite over the study area was 22, December 2002. Survey of India (SOI) topographical sheets of scale 1:50,000 were utilized for registration of satellite data, selection of ground control points and locating training sets as well as to identify and authenticate the various locations on satellite-image. The study area was digitized in Arc View GIS 3.2a; the shape file was then converted to Arc coverage file so that it can be imported in ERDAS Imagine 8.4 to delineate the study area in the satellite image. Crop water requirements were calculated using CROPWWAT.

\subsection{Study Area}

The Aliyar reservoir is an essential part of the Parambikulam Aliyar Project (an inter basin water transfer system) which is the major source of water for the coconut growing lands in the western 
regions of Tamil Nadu. The Aliyar reservoir acts as a balancing reservoir to receive surplus water through the Aliyar Feeder canal diverted from the Nirar, Sholayar and Parambikulam basin. An irrigation analysis was carried out for the Aliyar reservoir's command area. A better cropping pattern has been proposed for the study area and a daily irrigation schedule has been developed for the study area. The Pollachi canal and the Vettaikaranpudur canal are the two contour canals which supply water to agricultural land of area around 37000 acres from the Aliyar reservoir. The Aliyar dam was constructed in 1962 across the Aliyar river. Aliyar reservoir is situated between $10^{\circ} 15^{\prime}$ and $10^{\circ} 30^{\prime} \mathrm{N}$ and $76^{\circ} 50^{\prime}$ and $77^{\circ} 10^{\prime} \mathrm{E}$, at the FRL of $320.04 \mathrm{~m}$ above MSL. It is situated at $63 \mathrm{~km}$ from Coimbatore (i.e.) $24 \mathrm{~km}$ from Pollachi.

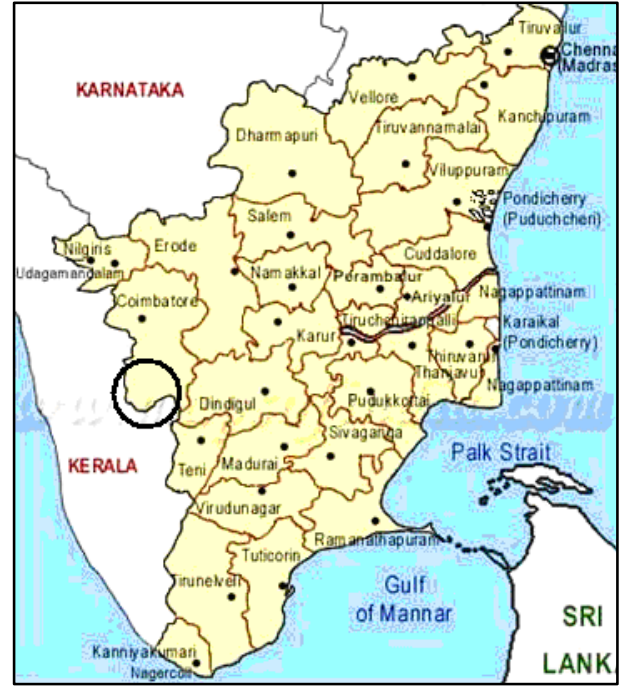

Fig 1:a Map of Tamil Nadu

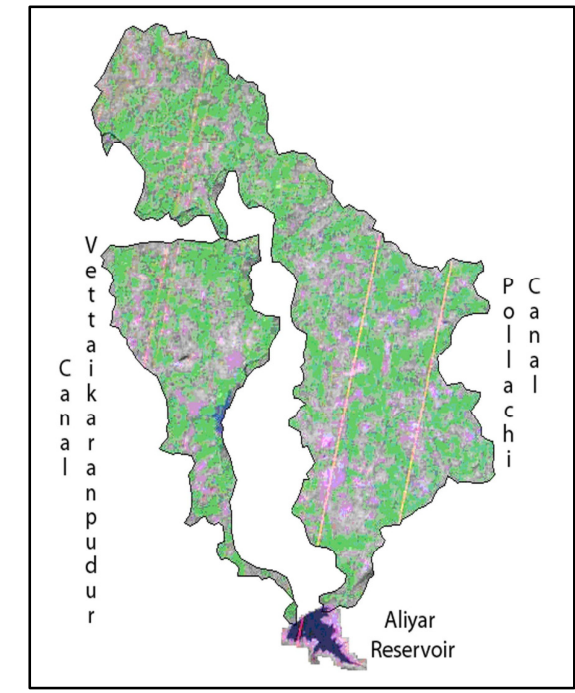

b Clipped satellite image delineating the study area

\section{Identification of the Cropping Pattern}

The satellite image was first georeferenced to convert the coordinates of the image to Latitude and Longitude. Georeferencing was done by selecting 14 ground control points identified using Survey of India topo-sheets. The map projection system was set to Universal Transverse Mercarter (UTM) 1983, Zone 43 which is corresponding to the study area. The cropping pattern was identified by performing supervised classification on the satellite image. Ground truth information was obtained by visits to the field and also by information from the local farmers. The image was classified into four classes namely Uncultivated land, Cultivated under coconut, Land under other crops, Water. 

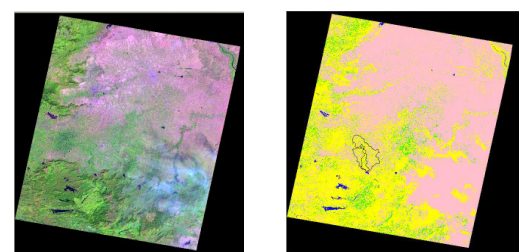

Fig 2: View of the original and classified (Supervised) satellite image as seen in the Viewer window of ERDAS Imagine 8.4

The study area was identified in the satellite image by overlaying the 'Vector' coverage on the satellite image. The vector layer was first digitized using Arc View GIS 3.2a. The shape files were then converted as coverage files using Data Automation Kit (DAK). After the classifying process, the area of land under each crop was calculated using the 'MEASURE' tool, available in ERDAS Imagine 8.4. The land use details are given in the Table

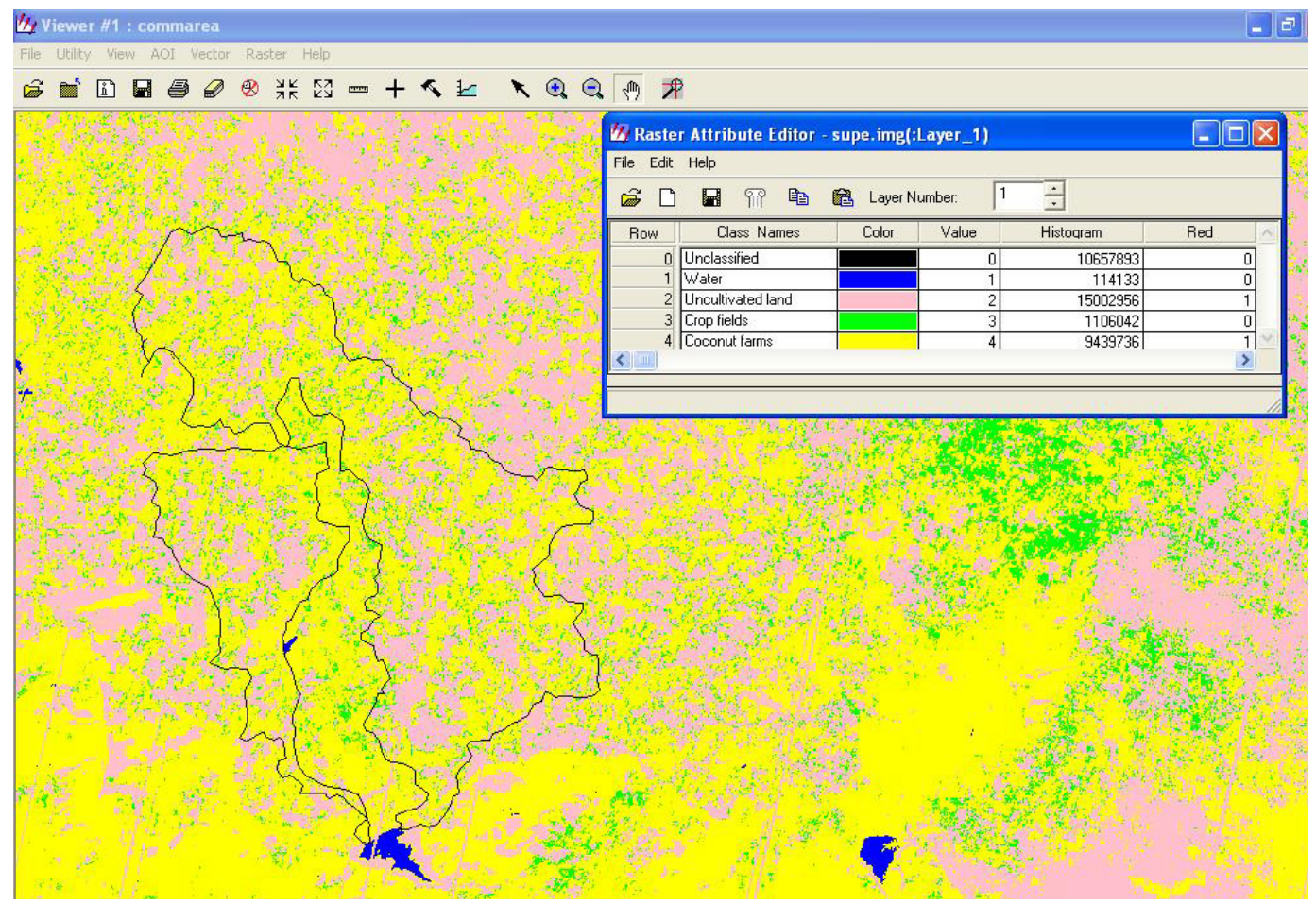

Fig 3: Satellite image classified into 4 classes using Supervised Classification

\begin{tabular}{|c|c|c|}
\hline & $\begin{array}{c}\text { Pollachi Canal } \\
\text { Command area }\end{array}$ & $\begin{array}{c}\text { Vettaikaranpudur } \\
\text { Canal Command area }\end{array}$ \\
\hline Total Command area (acres) & 26488 & 11284 \\
\hline Total Command area (hectares) & 10719.5 & 4566.6 \\
\hline
\end{tabular}




\begin{tabular}{|c|c|c|}
\hline Agricultural land under coconut (acres) & 19042 & 5472.6 \\
\hline Agricultural land under coconut (hectares) & 7706 & 2214 \\
\hline $\begin{array}{c}\text { Percentage of the total agricultural land under } \\
\text { coconut }\end{array}$ & 72 & 49 \\
\hline
\end{tabular}

Table 1: Land Use Pattern of the study area identified using ERDAS Imagine 8.4

\section{Present System of Agriculture and Irrigation}

The present system of agriculture involves the cultivation of crops only during one season of the year i.e. from June, July to October, November. Coconut being a perennial crop remains cultivated through out the year. Water is being released from the reservoir based on previous requirement records. The satellite image being recorded during December 2002, the crop that could be identified from the satellite image was coconut only, as the other agricultural land remained uncultivated during this season.

\subsection{Proposed System of Agriculture and Irrigation}

Since the present system of agriculture and irrigation are not based on any scientific principles an attempt was made in this research initiative to propose a new system of agriculture and irrigation. Accordingly a better cropping pattern has been suggested. The details of the proposed cropping pattern are,

In the Pollachi canal command area, Of the $20 \%$ of the total available agricultural land, Paddy is to be cultivated from April to August and Groundnut is to be cultivated from October to February.

$>$ In the Vettaikaranpudur canal command area, Of the $40 \%$ of the total available agricultural land, Paddy is to be cultivated from April to August and Groundnut is to be cultivated from October to February.

\subsection{CROPWAT}

CROPWAT is a DOS or Windows based decision support system designed by the Food and Agriculture Organization (FAO) of the United Nations. It was developed as a tool to help agronomists, and irrigation engineers carry out standard calculations for Evapo-Transpiration and crop water use studies, particularly the design and management of irrigation schemes. The package, CROPWAT is based on the Penman - Monteith equation for the calculation of the Evapo-Transpiration. It allows the development of recommendations for improved irrigation practices, the planning of irrigation schedules under varying water supply conditions, and the assessment of production under rain fed conditions or deficit irrigation. The CROPWAT database contains data for six continental regions and 144 countries. 


\subsection{Irrigation Scheduling Using CROPWAT}

The data relating the actual and proposed cropping pattern were input in CROPWAT to calculate the crop water requirements for the two command areas. The daily crop water requirement and irrigation schedule were developed. The condensed irrigation schedule for the Pollachi and Vettaikaranpudur Canal is given in Table 2 and Table 3.

\begin{tabular}{|c|c|c|c|c|c|c|c|c|}
\hline Date & Et $_{\mathrm{o}}$ & $\begin{array}{c}\text { Planted } \\
\text { Area }\end{array}$ & Crop $_{\mathrm{c}}$ & CWR & $\begin{array}{c}\text { Total } \\
\text { Rain }\end{array}$ & $\begin{array}{c}\text { Effec. } \\
\text { Rain }\end{array}$ & Irr Reqt & FWS \\
\hline & $\mathrm{mm} / \mathrm{per}$ & $\%$ & & $\mathrm{~mm} / \mathrm{per}$ & $\mathrm{mm} /$ per & $\mathrm{mm} /$ per & $\mathrm{mm} /$ per & 1/s/ha \\
\hline 1-Jan & 4.14 & 72 & 0.65 & 2.69 & 1.34 & 1.08 & 1.61 & 0.27 \\
\hline 15-Jan & 4.43 & 72 & 0.65 & 2.87 & 2.12 & 1.69 & 1.18 & 0.19 \\
\hline 1-Feb & 4.76 & 72 & 0.65 & 3.09 & 2.24 & 1.79 & 1.29 & 0.21 \\
\hline 15-Feb & 5 & 72 & 0.65 & 3.24 & 1.69 & 1.36 & 1.88 & 0.31 \\
\hline 1-Mar & 5.19 & 72 & 0.65 & 3.36 & 1.01 & 0.81 & 2.55 & 0.42 \\
\hline 15-Mar & 5.33 & 72 & 0.65 & 3.45 & 0.8 & 0.64 & 2.82 & 0.47 \\
\hline 1-Apr & 5.43 & 72 & 0.65 & 3.52 & 1.73 & 1.38 & 2.14 & 0.35 \\
\hline 15-Apr & 5.46 & 72 & 0.65 & 3.54 & 2.9 & 2.32 & 1.21 & 0.2 \\
\hline 1-May & 5.44 & 72 & 0.65 & 3.52 & 1.65 & 1.32 & 2.2 & 0.36 \\
\hline 15-May & 5.38 & 72 & 0.65 & 3.48 & 0 & 0 & 3.48 & 0.58 \\
\hline 1-Jun & 5.26 & 72 & 0.66 & 3.48 & 1.4 & 1.12 & 2.37 & 0.39 \\
\hline 15-Jun & 5.14 & 72 & 0.68 & 3.49 & 2.61 & 2.09 & 1.4 & 0.23 \\
\hline 1-Jul & 4.99 & 72 & 0.68 & 3.41 & 2.15 & 1.72 & 1.7 & 0.28 \\
\hline 15-Jul & 4.84 & 72 & 0.68 & 3.31 & 1.31 & 1.05 & 2.26 & 0.37 \\
\hline 1-Aug & 4.67 & 72 & 0.68 & 3.2 & 0.63 & 0.5 & 2.69 & 0.45 \\
\hline 15-Aug & 4.54 & 72 & 0.68 & 3.1 & 0.57 & 0.46 & 2.65 & 0.44 \\
\hline 1-Sep & 4.39 & 72 & 0.68 & 3 & 1.08 & 0.87 & 2.14 & 0.35 \\
\hline 15-Sep & 4.28 & 72 & 0.68 & 2.93 & 1.78 & 1.43 & 1.5 & 0.25 \\
\hline 1-Oct & 4.18 & 72 & 0.68 & 2.86 & 2.61 & 2.09 & 0.77 & 0.13 \\
\hline 15-Oct & 4.1 & 72 & 0.68 & 2.81 & 3.15 & 2.52 & 0.28 & 0.05 \\
\hline 1-Nov & 4.04 & 72 & 0.68 & 2.76 & 3.39 & 2.71 & 0.05 & 0.01 \\
\hline 15-Nov & 4 & 72 & 0.68 & 2.73 & 3.21 & 2.57 & 0.17 & 0.03 \\
\hline 1-Dec & 3.96 & 72 & 0.67 & 2.66 & 2.65 & 2.12 & 0.54 & 0.09 \\
\hline 15-Dec & 3.95 & 72 & 0.66 & 2.61 & 2.03 & 1.62 & 0.99 & 0.16 \\
\hline 25-Dec & 3.94 & 72 & 0.65 & 2.57 & 1.61 & 1.28 & 1.29 & 0.21 \\
\hline 31-Dec & 3.94 & 72 & 0.65 & 2.56 & 1.4 & 1.12 & 1.44 & 0.24 \\
\hline Total & 1714.5 & & & 1140.99 & 664.99 & 531.9 & 609.9 & 0.28 \\
\hline 1abe & & & & & & & & \\
\hline
\end{tabular}

Table 2: Condensed Daily irrigation schedule for the actual cropping pattern in Pollachi command area 


\begin{tabular}{|c|c|c|c|c|c|c|c|c|}
\hline Date & $\mathrm{Et}_{\mathrm{o}}$ & $\begin{array}{c}\text { Planted } \\
\text { area }\end{array}$ & Crop $_{\mathrm{c}}$ & CWR & $\begin{array}{c}\text { Total } \\
\text { Rain }\end{array}$ & $\begin{array}{c}\text { Effec } \\
\text { Rain }\end{array}$ & Irr Reqt & FWS \\
\hline & $\mathrm{mm} / \mathrm{per}$ & $\%$ & & $\mathrm{~mm} / \mathrm{per}$ & $\mathrm{mm} / \mathrm{per}$ & $\mathrm{mm} / \mathrm{per}$ & $\mathrm{mm} /$ per & 1/s/ha \\
\hline 1-Jan & 4.14 & 49 & 0.44 & 1.83 & 0.91 & 0.73 & 1.1 & 0.18 \\
\hline 15-Jan & 4.43 & 49 & 0.44 & 1.95 & 1.44 & 1.15 & 0.8 & 0.13 \\
\hline 1-Feb & 4.76 & 49 & 0.44 & 2.1 & 1.53 & 1.22 & 0.88 & 0.15 \\
\hline 15-Feb & 5 & 49 & 0.44 & 2.2 & 1.15 & 0.92 & 1.28 & 0.21 \\
\hline 1-Mar & 5.19 & 49 & 0.44 & 2.29 & 0.69 & 0.55 & 1.74 & 0.29 \\
\hline 15-Mar & 5.33 & 49 & 0.44 & 2.35 & 0.54 & 0.43 & 1.92 & 0.32 \\
\hline 1-Apr & 5.43 & 49 & 0.44 & 2.39 & 1.17 & 0.94 & 1.46 & 0.24 \\
\hline 15-Apr & 5.46 & 49 & 0.44 & 2.41 & 1.98 & 1.58 & 0.83 & 0.14 \\
\hline 1-May & 5.44 & 49 & 0.44 & 2.4 & 1.13 & 0.9 & 1.5 & 0.25 \\
\hline 15-May & 5.38 & 49 & 0.44 & 2.37 & 0 & 0 & 2.37 & 0.39 \\
\hline 1-Jun & 5.26 & 49 & 0.45 & 2.37 & 0.95 & 0.76 & 1.61 & 0.27 \\
\hline 15-Jun & 5.14 & 49 & 0.46 & 2.38 & 1.78 & 1.42 & 0.96 & 0.16 \\
\hline 1-Jul & 4.99 & 49 & 0.47 & 2.32 & 1.46 & 1.17 & 1.15 & 0.19 \\
\hline 15-Jul & 4.84 & 49 & 0.47 & 2.26 & 0.89 & 0.72 & 1.54 & 0.25 \\
\hline 1-Aug & 4.67 & 49 & 0.47 & 2.17 & 0.43 & 0.34 & 1.83 & 0.3 \\
\hline 15-Aug & 4.54 & 49 & 0.47 & 2.11 & 0.39 & 0.31 & 1.8 & 0.3 \\
\hline 1-Sep & 4.39 & 49 & 0.47 & 2.04 & 0.74 & 0.59 & 1.45 & 0.24 \\
\hline 15-Sep & 4.28 & 49 & 0.47 & 1.99 & 1.21 & 0.97 & 1.02 & 0.17 \\
\hline 1-Oct & 4.18 & 49 & 0.47 & 1.94 & 1.78 & 1.42 & 0.52 & 0.09 \\
\hline 15-Oct & 4.1 & 49 & 0.47 & 1.91 & 2.15 & 1.72 & 0.19 & 0.03 \\
\hline 1-Nov & 4.04 & 49 & 0.47 & 1.88 & 2.31 & 1.85 & 0.03 & 0.01 \\
\hline 15-Nov & 4 & 49 & 0.47 & 1.86 & 2.18 & 1.75 & 0.11 & 0.02 \\
\hline 1-Dec & 3.96 & 49 & 0.46 & 1.81 & 1.81 & 1.44 & 0.37 & 0.06 \\
\hline 15-Dec & 3.95 & 49 & 0.45 & 1.78 & 1.38 & 1.1 & 0.67 & 0.11 \\
\hline 31-Dec & 3.94 & 49 & 0.44 & 1.74 & 0.95 & 0.76 & 0.98 & 0.16 \\
\hline Total & 1714.5 & & & 776.51 & 452.56 & 361.99 & 414.52 & 0.19 \\
\hline
\end{tabular}

Table 3: Condensed Daily irrigation schedule for the actual cropping pattern in Vettaikaranpudur command area

The water requirement was calculated for the coconut crop only. Similarly the water requirement for the proposed cropping pattern is provided in Table 4 and Table 5. One of the major disadvantages of CROPWAT is that, only one scheduling criteria can be specified during analysis. Hence to simulate the different criteria for the crops, analyses were done three times for each crop, i.e separately for Coconut, Paddy and Groundnut. 


\begin{tabular}{|c|c|c|c|c|}
\hline Date & $\begin{array}{l}\text { Effective } \\
\text { Rainfall }\end{array}$ & $\begin{array}{c}\text { FWS } \\
\text { Coconut }\end{array}$ & $\begin{array}{c}\text { FWS } \\
\text { Groundnut }\end{array}$ & $\begin{array}{l}\text { FWS } \\
\text { Paddy }\end{array}$ \\
\hline & $\mathrm{mm} /$ period & 1/s/ha & l/s/ha & 1/s/ha \\
\hline 1-Jan & 1.08 & 0.27 & 0.13 & - \\
\hline 15-Jan & 1.69 & 0.19 & 0.11 & - \\
\hline $1-\mathrm{Feb}$ & 1.79 & 0.21 & 0.07 & - \\
\hline $15-\mathrm{Feb}$ & 1.36 & 0.31 & 0.06 & - \\
\hline 1-Mar & 0.81 & 0.42 & - & - \\
\hline 15-Mar & 0.64 & 0.47 & - & - \\
\hline 1-Apr & 1.38 & 0.35 & - & 0 \\
\hline 15-Apr & 2.32 & 0.2 & - & 0 \\
\hline 1-May & 1.32 & 0.36 & - & 0 \\
\hline 15-May & 0 & 0.58 & - & 0.12 \\
\hline 1-Jun & 1.12 & 0.39 & - & 0.15 \\
\hline 15-Jun & 2.09 & 0.23 & - & 0.11 \\
\hline 1-Jul & 1.72 & 0.28 & - & 0.12 \\
\hline 15-Jul & 1.05 & 0.37 & - & 0.15 \\
\hline 1-Aug & 0.5 & 0.45 & - & 0.13 \\
\hline 15-Aug & 0.46 & 0.44 & - & 0.06 \\
\hline 1-Sep & 0.87 & 0.35 & - & - \\
\hline 15-Sep & 1.43 & 0.25 & - & - \\
\hline 1-Oct & 2.09 & 0.13 & 0 & - \\
\hline 15 -Oct & 2.52 & 0.05 & 0 & - \\
\hline 1-Nov & 2.71 & 0.01 & 0 & - \\
\hline 15-Nov & 2.57 & 0.03 & 0 & - \\
\hline 1-Dec & 2.12 & 0.09 & 0.05 & - \\
\hline 15-Dec & 1.62 & 0.16 & 0.09 & - \\
\hline 31-Dec & 1.12 & 0.24 & 0.12 & - \\
\hline Total & & 0.28 & 0.05 & 0.09 \\
\hline
\end{tabular}

Table 4: Condensed, Modified schedule table indicating the Effective Rain and the Water Requirement of Coconut, Groundnut, Paddy in Pollachi command area

Since Paddy is to be cultivated from April to August and Groundnut is to be cultivated from October to February, it can be noted from the table that the water requirement corresponds to the cultivation of crops in the region.

\begin{tabular}{|c|c|c|cc|c|}
\hline Date & $\begin{array}{c}\text { Effective } \\
\text { Rainfall }\end{array}$ & $\begin{array}{c}\text { FWS } \\
\text { Coconut }\end{array}$ & FWS & Groundnut & $\begin{array}{c}\text { FWS } \\
\text { Paddy }\end{array}$ \\
\hline & $\mathrm{mm} /$ period & $1 / \mathrm{s} / \mathrm{ha}$ & $1 / \mathrm{s} / \mathrm{ha}$ & $1 / \mathrm{s} / \mathrm{ha}$ \\
\hline 1-Jan & 0.75 & 0.18 & 0.25 & - \\
\hline
\end{tabular}




\begin{tabular}{|c|c|c|c|c|}
\hline 15-Jan & 1.15 & 0.13 & 0.21 & - \\
\hline 1-Feb & 1.22 & 0.15 & 0.15 & - \\
\hline $15-\mathrm{Feb}$ & 0.92 & 0.21 & 0.13 & - \\
\hline 1-Mar & 0.55 & 0.29 & - & - \\
\hline 15-Mar & 0.43 & 0.32 & - & - \\
\hline 1-Apr & 0.94 & 0.24 & - & 0 \\
\hline 15-Apr & 1.58 & 0.14 & - & 0 \\
\hline 1-May & 0.9 & 0.25 & - & 0 \\
\hline 15-May & 0 & 0.39 & - & 0.24 \\
\hline 1-Jun & 0.76 & 0.27 & - & 0.3 \\
\hline 15-Jun & 1.42 & 0.16 & - & 0.21 \\
\hline 1-Jul & 1.17 & 0.19 & - & 0.24 \\
\hline 15-Jul & 0.72 & 0.25 & - & 0.3 \\
\hline 1-Aug & 0.34 & 0.3 & - & 0.26 \\
\hline 15-Aug & 0.31 & 0.3 & - & 0.13 \\
\hline 1-Sep & 0.59 & 0.24 & - & - \\
\hline 15-Sep & 0.97 & 0.17 & - & - \\
\hline 1-Oct & 1.42 & 0.09 & 0 & - \\
\hline 15 -Oct & 1.72 & 0.03 & 0 & - \\
\hline 1-Nov & 1.85 & 0.01 & 0 & - \\
\hline 15-Nov & 1.75 & 0.02 & 0 & - \\
\hline 1-Dec & 1.44 & 0.06 & 0.11 & - \\
\hline 15-Dec & 1.1 & 0.11 & 0.18 & - \\
\hline 31-Dec & 0.76 & 0.16 & 0.23 & - \\
\hline Total & & 0.19 & 0.1 & 0.18 \\
\hline
\end{tabular}

Table 5: Condensed, Modified schedule table indicating the Effective Rain and the Water Requirement of Coconut, Groundnut, Paddy in V.Pudur command area

Based on the total area under each crop, the water requirement in the units of $\mathrm{m}^{3} / \mathrm{s}$ was calculated for each case. Later, the water requirement for a year can also be calculated.

\section{Results}

After the completion of the irrigation analyses, the crop water requirements for the various cases are,

Water requirement for the actual cropping pattern (for coconut crop only) $=\mathbf{8 1 . 7 1}$ Million $\mathrm{m}^{3}$ $=(2.871 \mathrm{TMcft})$

Actual volume of water released from the reservoir $=\mathbf{2 6 2 . 2 5}$ Million $\mathrm{m}^{3}$ $=(9.213 \mathrm{TMcft})$

Water requirement for the proposed cropping pattern (for coconut, paddy $=\mathbf{1 9 0 . 8 6 7}$ Million $\mathrm{m}^{3}$ and groundnut) $=(6.71 \mathrm{TMcft})$ 

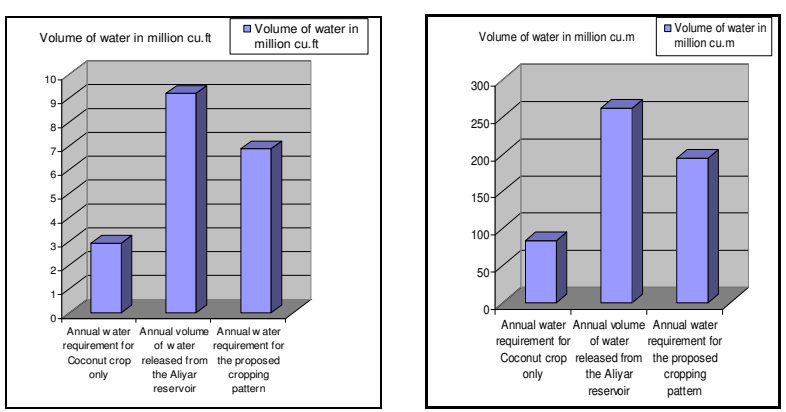

Fig 4: Charts showing the comparison of water requirements for the actual cropping pattern, proposed cropping pattern and water released

The occurrence of rainfall can be an important factor in the growth of crops in an area. The crop water requirement is directly related to the rainfall. At the end of this study, a correlation between the effect of occurrence of rainfall and the water requirement in the fields has been made which is shown in Figure 4 and Figure 5. It can be seen that rainfall is an important factor in the calculation of water requirement. Therefore it is essential that accurate rain forecasting systems be developed so that irrigation automation can be brought about.

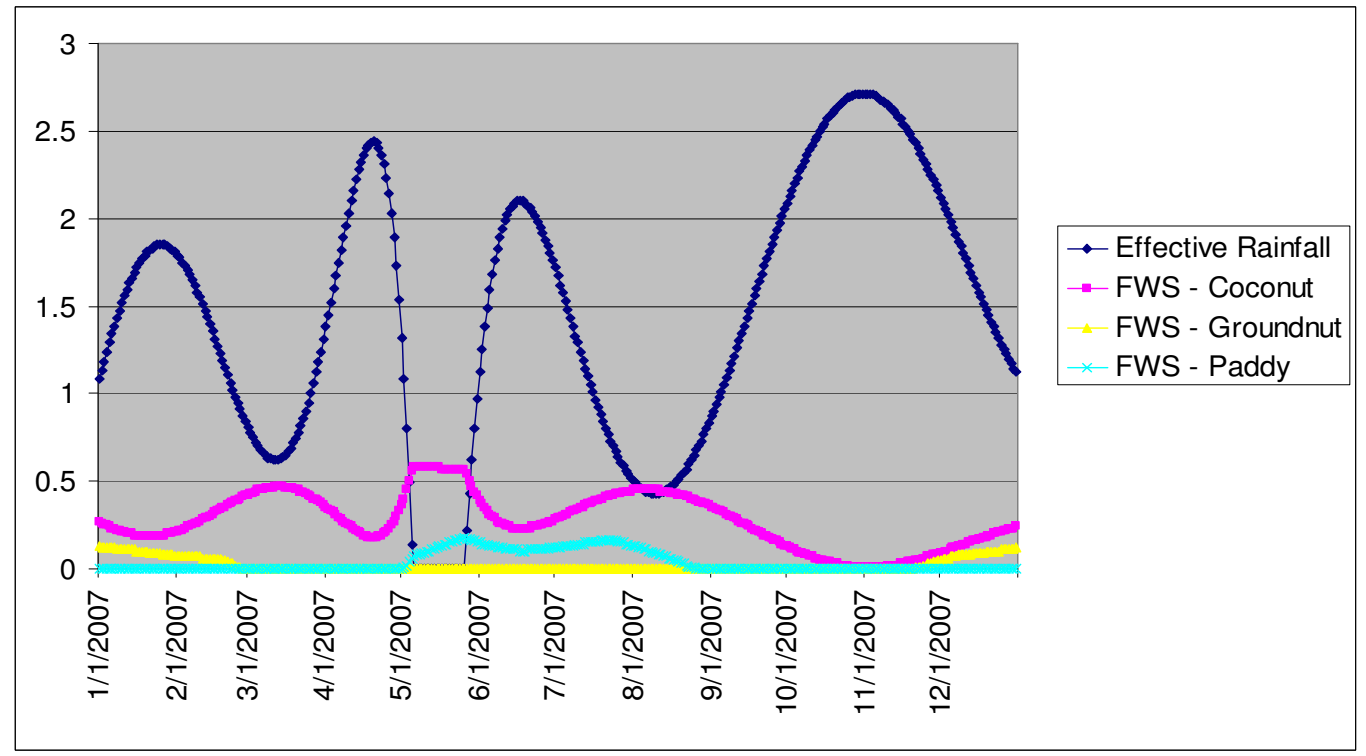

Fig 5: Graph, correlating the occurrence of rainfall and the water requirement in the fields in Pollachi region for the Proposed cropping pattern 


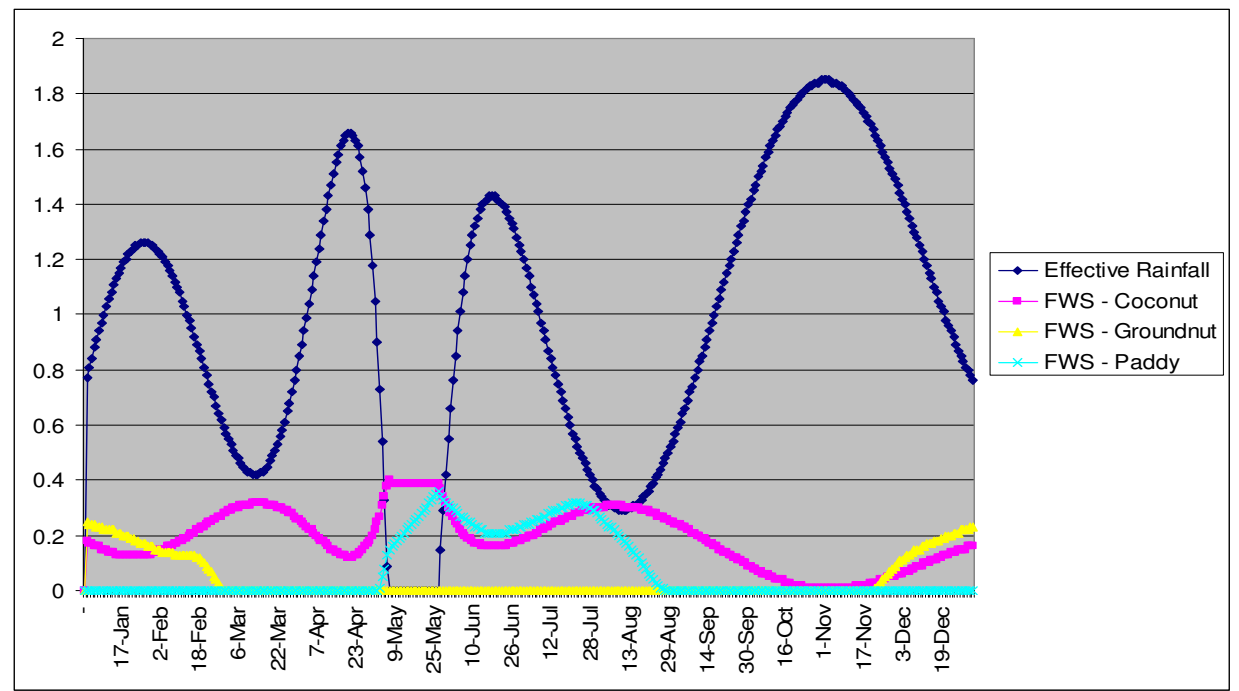

Fig 6: Graph, correlating the occurrence of rainfall and the water requirement in the fields in Vettaikaranpudur region for the Proposed cropping pattern

\section{Assumptions}

The following assumptions were made in carrying out this project,

The satellite image that was obtained was taken on December 22, 2002. Hence all the irrigation analyses carried out for the actual cropping pattern are for the condition that was present in the field during this period.

$>$ In the months of December, only the coconut crop was found to be cultivated in the study area and the remaining agricultural land was left uncultivated. Hence the water requirement calculated for the actual case is inclusive of the water requirement for the coconut crop only.

$>$ In order to make a comparison between the actual system and the proposed system, the amount of water released from the Aliyar reservoir during the agricultural year 2002-03 has been used.

\section{Conclusions}

Performance analysis for a part of the Parambikulam Aliyar Project i.e., the command area of Aliyar reservoir was performed. A daily irrigation schedule indicating the amount of water to be supplied to the fields was prepared for the study area. A better cropping pattern was also proposed for the study area. The conclusions that can be arrived at are,

$>$ Implementing the proposed cropping pattern could bring about a savings of about $27 \%$ in the irrigation water supplied to the fields in the study. 
Apart from the savings in water, increased production of crops would be possible as it has been proposed to cultivate during two seasons of a year.

$>$ The adoption of the proposed cropping pattern depends on the mindset of the farmers, but the government can play a proactive role in persuading the farmers to adopt the better system so that all round advantage can be derived.

$>$ A system has to be setup in such a way that the actual water requirements of the crops are calculated and irrigation is done according to the actual needs of the crops.

$>$ Similar to the way by which town planning studies are carried out before the process of developing a town or city, dedicated command area planning studies have to be undertaken so that specific methods of irrigation and agriculture can be adopted for that particular command area.

$>$ Irrigation of fields daily can help in reducing losses; since the soil could be kept always moist hence infiltration would be reduced.

$>$ Also the practice of irrigating the fields daily would help in increasing the yield of the crop since water is available to the crop whenever it is needed.

$>$ For irrigation automation to be successful, efficient and accurate, better weather forecasting systems and methods are necessary so that the likely rainfall and drought can be predicted in advance and necessary actions be taken.

\section{REFERENCES}

[1]. Bastiaanssen, W. G. M. and S. Ali. 2003. A new crop yield-forecasting model based on satellite measurements applied across the Indus basin, Pakistan. Agriculture Ecology and Environment 94, 3, 321-340.

[2]. Doorenbos J and Pruitt WO. FAO (Food and Agriculture Organization),1975. Guidelines for predicting crop water requirement. Irrigation and Drainage paper 24, Rome, Italy.

[3]. Elangovan. K, (2006). " GIS Fundamentals, Applications and Implementations ", New India Publishing ,New Delhi

[4]. Ravi G P, (2005). Remote Sensing Geology. Springer (India) Private Limited, New Delhi.

[5]. Pat Hohl (1998). GIS Data Conversion: Strategies, Techniques, Management. OnWord Press, New Mexico.

[6]. Sechler, D., U. Amarasinghe, D. Molden, R. De Silva, and r. Barker. 1998. World water demand and supply, 1990 to 2025: Scenarios and Issues. Research Report No. 19. Colombo: International Irrigation Management Institute.

[7]. Zhao, G.X., Dou, Y. X., Tian, W.X., and Zhang, Y. H. 2001. Study on automatic abstraction methods of cultivated land information from satellite remote sensing images viewed in Cultivated land changes and their driving forces-A satellite remote sensing analysis in yellow river delta china. Pedosphere 14(1): 93-102, 2004. 